\title{
SDGs 실행을 위한 자원봉사의 \\ 변혁적 파트너십 추진전략
}

목 차

I. 머리말

II. 자원봉사의 ‘변혁적' 파트너십 추진전략

1. '변혁적 거버넌스'와 자원봉사

2. 글로벌 파트너십 전략

III. SDGs 달성에 기여하는 자원봉사의 임팩트

1. 자원봉사의 인적/사회적 자본 임팩트

2. SDGs 달성에 기여하는 자원봉사의 임팩트

IV. SDGs 실행을 위한 자원봉사 파트너십 추진 방안

1. 위, 아래, 밖으로부터의 공조

2. 정부의 자원봉사 제도화 지원방안

3. 기업의 '포용적 비즈니스' 지원방안

4. 시민사회의 '역량 강화’ 지원방안

5. 국내-국제 자원봉사의 통합 추진전략

V. 맺는말

참고문헌 


\section{요 약}

국제사회는 자원봉사가 SDGs 달성에 강력한 수단이라는 인식과 함께, SDGs 17 개 전체가 자원봉사에 의존해, 자원봉사가 생산하는 사회적, 경제적 가치들을 SDGs의 중요한 임팩트로 간주한다. '변혁적 거버넌스' 추진전략을 제시하는 UNV는 특히 SDGs 달성의 핵심을 거버넌스에 초점을 맞춰 추진전략을 강조한다. 자원봉사를 개발도상국의 $\mathrm{SDGs}$ 추진 전략으로 활용하는 방안은, 국제사회 파트너들인 정부/국제기관, 기업/기업 연맹, $\mathrm{NGO/글로벌} \mathrm{네트워크} \mathrm{각각의} \mathrm{개발도상국의} \mathrm{국가(정부),} \mathrm{시장(기업),} \mathrm{시민사회}$ ( $\mathrm{NGO}$ /자원봉사조직)을 공조적 파트너십으로 지원하는 방안들이 있다. 개발도상국 자 원봉사 진흥을 지원하기 위해 개도국 국내의 자원봉사와 국제사회의 자원봉사가 연계, 통합이 이뤄질 필요가 있다. 국내 봉사자와 국제봉사자가 SDGs 분야별로 프로젝트나 프로그램 단위에서 공조함으로써 SDGs 달성에 시너지 효과를 발휘될 수 있다. 특히 국제봉사자들의 지식, 경험, 전문기술이 국내봉사자들에게 전수·보급되어, 개발의 오 너십과 역량 강화 전략으로 추진될 수 있을 때 개발협력의 지속가능한 임팩트를 기대할 수 있다.

주제어 : SDGs, 자원봉사(volunteering), 공조적 파트너십(collaborative partnership), 변혁적 거버넌스(transformative governance)

\section{I . 머리말}

지속가능개발목표(Sustainable Development Goals, 이하 SDGs)의 본격적인 시행으로 글로벌, 국가, 지역, 지방 등 다차원에서 공공, 민간, 사회 등 3섹터의 자원봉사 진흥 역할이 주목되고 있다. 자원봉사(volunteering)의 '세계화' 추세에서 개발도상국 자원봉사도 활성화되 고 있어, SDGs 달성에 자원봉사의 기여에 대한 관심 또한 고조되고 있다. 자원봉사 참여도는 아시아, 아프리카 등 개발도상국에서도 이제 글로벌 평균수준에 근접해있다(CAF, 2016). $\operatorname{UNV}(2009,2011)$ 는 2001년 '국제 자원봉사자의 해(International Year for Volunteers)' 이후 8 년간 70 여 국에서 국가 리더십의 의지로 관련법과 제도가 도입된 것이 중요한 글로벌 동향이라 평가한다. 
국제연합(United Nations, 이하 UN) 등 국제사회는 자원봉사가 SDGs 달성에 강력한 수단 이라는 인식과 함께, SDGs 17 개 전체가 자원봉사에 의존해, 자원봉사가 생산하는 사회적, 경제적 가치들을 SDGs의 중요한 임팩트로 간주한다. 자원봉사의 경제적 가치 측정을 추진하는 국제노동기구(ILO, 2011)에 따르면, '자원봉사'는 "자원봉사자 자신의 가계나 친지가 아닌 타인 의 이익을 위해 법적 강제에 의하지 않고 금전적 지급이나 보상이 없는 활동(work)"이라 정의 한다. 또 UN은 자원봉사가 개인의 “자유의지에서 공공선을 위한, 금전적 보상이 주요 동기가 아닌” 광범위한 활동이라 정의한다(UNV, 2015c).

$\mathrm{SDGs}$ 시행에 앞서 2015년 UN 총회는 “자원봉사가 2030 지속가능개발 어젠다(이하, 2030 어젠다)의 실행에서 강력한 수단" 으로 중시해, “자원봉사를 2030 어젠다와 관련 핵심 문건에 통합” 할 것을 공표하였다(UNGA, 2015). 이에 따라 국제연합봉사단(United Nations Volunteer, 이하 $\mathrm{UNV}$ )는 2016-30년 기간 개발과 평화에 자원봉사를 통합하는 행동 계획에서 1) 시민참여의 증진과 시민행동을 진흥하는 환경 개선으로 개발 어젠다의 국민의 오너십 강화, 2) SDGs 달성을 위해 자원봉사를 국가와 글로벌 실행 전략에 통합하는 추진전략으로 제시하였다(UNV, 2015a).

한편 SDGs는 사회-경제-환경적 목표를 추구하는 '지속가능한(sustainable)' 개발이며 모 든 국가가 대상이 되는 보편적(universal) 특성과 접근법의 총체적인(holistic) 특성뿐 아니라 다른 네 가지 특성이 있다(UN, 2015a; UNV, 2015a). 그것들은 변혁적(transformative), 글로벌 파트너십(Global Partnership), 사람과 참여(People and Participation) 특성이다. 이 논문은 후자 세 가지 특성 측면에서 SDGs 실행에 기여하는 자원봉사의 이론과 정책, 시행 전략과 추진 방안에 관한 논의를 진행한다.

먼저 SDGs의 ‘변혁적' 특성은 인권 기초, 거버넌스, 지역 기반, 사람과 참여의 중요성에 초점을 맞춘다(UN, 2015a; UNV, 2015a). 인권 기초(human rights-based)에서는 자원봉사 가 추구하는 인권과 권리 기반의 개발이 중시된다. 또 거버넌스(governance)에서는 개발의 오너십이 국가뿐 아니라 국민에게 부여되는 새로운 변혁이 자원봉사를 통해 진전될 것으로 강조한다. 또 '지역 기반(local dimension)'은 자원봉사가 지역사회 문제 해결에 지역주민들 의 자원봉사 참여로 정착될 필요성을 보여준다. '포용적(inclusive)' 특성에서는 자원봉사가 모든 시민의 참여를 지향하므로 SDGs의 포용적 개발 추진에 적합한 수단이자 목표라 강조 한다.

또 SDGs의 '글로벌 파트너십’은 개발도상국의 개발 성과와 임팩트는 개발도상국 국가와 
지방 차원뿐 아니라 글로벌 차원의 지원이 결합된 다차원 파트너십 전략으로 SDGs를 추진할 것을 제시한다. 동시에 정부 등의 국가 주도적인 사고와 방식의 변혁이 되는 거버넌스 차원에서 국가-시장-시민사회, 또는 정부-기업-NGO 사이의 공조적 파트너십도 변혁적 거버넌스의 핵심 전략이 된다. 나아가 SDGs의 '사람과 참여' 특성은 왜 SDGs 달성에 자원봉사가 중요한 역할을 하는지를 잘 보여준다. 국민의 자발적인 참여에 기초하지 않은 개발은 거버넌스의 원칙 이나 포용적 개발이 이뤄지지 않아 변혁적 개발을 기대할 수 없다.

\section{II. 자원봉사의 ‘변혁적’ 파트너십 추진전략}

\section{1. '변혁적 거버넌스' 와 자원봉사}

변혁(transformation)'과 파트너십(partnership)은 SDGs의 디자인 단계부터 중시된 핵심 개념들이다. 2005년 원조효과성에 관한 파리 선언 이후 개발의 국가 오너십이 중시되면서, 공공기관의 책무성과 개발의 효과성 전략들이 추진되어 왔다. 2010년 이스탄불의 시민사회단체 (civil society Organization, CSO) 개발효과성 원칙들이 채택되면서 활성적인 시민사회와 시민참여에 초점을 맞춘 개발 전략들이 디자인되고 추진되었다. 파리 선언과 이스탄불 원칙들은 포스트 2015 어젠다 설정에서 재확인되며, UN 포스트 2015 어젠다 고위 패널은 '효과적, 개방 적, 책무적 기관'과 그리고 연대, 협력, 상호 책무성에 기초하는 '새로운 글로벌 파트너십'을 새로 운 사람 중심의 개발 패러다임에 필수적인 결정적으로 중요한 '변혁적 이동(transformative shift)'으로 파악하였다(UNGA, 2015). 변혁적 이동은 개발을 하는 방식의 변혁을 의미하는 것으로, 전통적인 방식이 되는 기술적 투입과 재정 지원에 초점을 맞추는 개발협력 방식에서 변화와 권력의 협상이 이뤼지는 과정과 인간관계를 중시하는 접근방식으로의 이동을 의미한다 (VSO, 2016:1).

또 2014년 UN 사무총장은 『2030년까지의 존엄성을 지향하는 여정』보고서에서 SDGs 달성이 '변혁적 접근'에 기초할 것으로 강조하였다. 앞서 제시한 보편성, 지속가능성, 불평등, 인권을 완전하게 추구하는 변혁을 의미한 것이다. UN은 '진정한 보편적인 지속가능한 개발의 변혁'을 이루기 위한 몇 가지 추진전략을 제시하였다. 1) 모든 국가, 모든 집단의 문제 해결을 포함하는 보편적 접근법을 시행하며, 2) 경제적, 환경적, 사회적 임팩트에 초점을 맞춰, 모든 활동에 지속가능성을 통합하고, 3) 모든 영역에서 불평등에 초점을 맞춰, 어떤 목표나 타겟도 모든 사회적, 경제적 집단들을 위해 충족되지 않으면 충족된 것으로 간주되지 않은 것으로 
이해하며, 4) 모든 행동들이 국제 기준에 완전하게 합치되는 인권을 존중하고 진전시킨다(UN, 2014).

‘변혁적 거버넌스' 추진전략을 제시하는 UNV는 특히 SDGs 달성의 핵심을 거버넌스에 초점 을 맞춰 추진전략을 강조한다. 거버넌스는 국가의 중앙과 지방, 모든 차원에서 '국정을 관리하는 경제, 정치, 행정 당국의 권위의 행사'와 관련되는데, 특히 '시민들과 집단들이 자신의 이해를 표출해, 법률적 권리를 행사하고 의무를 수행하며 격차를 조정하는 메커니즘, 과정 및 제도들'을 의미한다(UNDP, 1997:2). 자원봉사는 '굿 거버넌스(good governance)'의 핵심 기반이 되는 주창, 참여, 책무성과 호응성을 증진시키는 기술, 지식 및 전문역량을 동원하는 매개수단으로 개발 문제 해결과 자원을 보충해주는 기능을 한다. SDGs 달성은 거버넌스의 개선을 통해 불평등 해소와 국민들의 요구와 참여의 충족에 절대적으로 의존할 수밖에 없다. 자원봉사는 개발의 이해관계자인 국민들의 요구를 경청하고 국민들과 $\mathrm{CSO}$ 들이 개발협력의 주체로 참여해 문제 해결에 기여하도록 한다.

거버넌스가 개발의 주요 추진전략으로 중시된 배경에는 새천년개발목표(Millennium Development Goals, 이하 MDGs) 추진과정에서 확인되었다. MDGs가 완료되면서 성과와 문제에 대한 다양한 논의에서 특히 개발과정에 국민들의 참여와 관여 부족 문제, 굿 거버넌스와 책무성(accountability) 문제들이 심각하게 제기되었다(UNV, 2016:2). 거버넌스는 2011년 부산 원조 효과성(aid effectiveness) 총회에서 글로벌 이슈로 부각되었다. 원조의 효과성 개선 과제는 2003년 로마에서 개시되어 2005년 파리에서 개발되었으며, 2008년 아크라에서 완전한 논의가 이뤄졌다. 파리 총회는 개발 어젠다의 중심에 국가 오너십(national ownership)을 원조 효과성 전략으로 제시했고, 아크라에서는 상호 책무성(mutual accountability)이 제안되었다. 부산 총회는 시민사회 대표를 완전히 동등한 파트너로 포용한 최초의 포럼이 되면서 정부 주도 의 거버먼트 모델에서 정부-시민사회-기업 공조의 거버넌스 접근을 새로운 비전으로 제시하였 다. 시민참여를 진흥하는 정부의 환경 조성 정책도 요청되었다. 지속가능한 개발은 모든 시민사 회 행위자들의 참여에 의존한다는 것으로 재인식한 것이다. SDGs는 사람 중심의 개발을 중시 하며 자원봉사가 지속가능한 개발의 강력한 도구라는 점을 강조한다.

\section{2. 글로벌 파트너십 전략}

$\mathrm{UNV}(2015 \mathrm{~b})$ 는 『자원봉사가 SDGs 달성에 기여하는 방법』보고서에서 SDGs 달성의 일차 적인 책임은 정부와 국민들로 밝히면서, 글로벌 파트너십을 실행전략으로 제시한다. 국가 차원 의 SDGs 달성을 추진하는 정부의 파트너로는 공공기관들뿐 아니라 기업, 지역사회, 시민사회, 
개발기관 등 거의 모든 기관과 단체들을 망라한다. 특히 국가(정부), 시장(기업), 시민사회 $(\mathrm{CSO})$ 가 국가개발계획의 수립 단계부터 공조적 파트너로 참여해, 기획해 수행하고 임팩트를 창출하는 '집단적 임팩트(collective impact)' 파트너가 될 수 있을 때 개발협력의 임팩트, 즉 $\mathrm{SDGs}$ 의 달성도가 최대화될 수 있다. 이 같은 삼각 파트너십 추진은 풀뿌리 지역사회부터 국가 차원과 글로벌 차원에서 통합적으로 추진될 지속가능한 개발협력의 임팩트를 창출할 수 있다(UNV, 2015c:xiv).

먼저 지역사회 차원에서는 주민과 $\mathrm{CSO}$ 의 역량 개발과 강화에 초점을 맞출 수 있다. 지방 차원의 민주적 거버넌스의 시행을 위해 일반 주민뿐 아니라 소외층, 취약층은 개방적으로 참여 할 수 있는 '포용적' 참여가 중요하다. 여성, 장애인 등 취약층의 욕구와 요구가 정책기획과 결정에 반영되고 실제로 집행될 수 있도록 지방 풀뿌리 차원부터 참여적 거버넌스가 정착될 필요가 있다.

자원봉사는 정부와의 공조적 파트너십으로 주요 거버넌스 이슈들에 초점을 맞춰 사회통합과 사회문제 해결의 전략으로 중시될 수 있다. 정부 주도적 방안과 시민사회 주도적 방안으로 구분해 살펴보면, 한국을 포함한 많은 $\mathrm{OECD}$ 국가들도 이 두 방안을 복합적으로 활용하고 있다(주성수, 2013). 첫째는 정부가 법과 제도를 마련하거나 자원봉사센터를 설립해 민간 전문 가들과 자원봉사자들이 국정 현안의 해결에 공조적 파트너로 참여하도록 하는 방안이다. 한국에 서도 조례에 의해 그리고 2006년 자원봉사활동기본법이 시행되어 전국 시도와 시군구에 자원봉 사센터가 설치되어 정부의 예산지원과 행정관리로 민간 전문가들의 센터운영으로 이뤼진 민관 공조체제를 이루고 있다(주성수, 2013, 2016a). 미국이나 영국 등지에서도 정부는 법과 제도와 재정지원을 통해 자원봉사 진흥 정책을 추진하며, 운영의 주체는 민간 전문가와 $\mathrm{CSO}$ 들이 맡는 공조적 파트너십이 특징이다(주성수, 2013; 주성수 외, 2012). 둘째는 민간 주도적인 방안으로, 정부 주도적 방안보다는 쉽지 않지만 민간 자율적으로 자원봉사의 기획-운영-평가 등을 전담하 는 자율적 방안이 민주적 거버넌스 이념에 적합하다. 한국을 비롯한 대부분의 $\mathrm{OECD}$ 국가들의 자원봉사조직들은 자원봉사센터의 경우처럼 정부 주도적인 경우가 일부 있지만 대부분은 CSO 주도, 민간 주도적이다(주성수, 2013). 개발도상국에서는 대표적인 사례가 되는 온두라스, 모잠 비크, 칠레에서 정부가 자원봉사 법 제정에 다양한 이해관계자들과 공조하는 거버넌스가 비교적 잘 이뤄진 것으로 평가되고 있다(UNV, 2015c:39-40).

국가 차원에서는 중앙 정부 부처들이 자원봉사 제도화를 통해 다양한 계층의 자원봉사 참여 를 통한 사회통합을 지향하는 정책을 도입할 수 있다. SDGs 17 개 목표마다 자원봉사 활용의 정책디자인 작업부터 정부기관뿐 아니라 $\mathrm{CSO}$ 와 시민대표들이 고루 참여하는 거버넌스를 시행 
해 바람직한 정책결정과 집행으로 추진될 필요가 있다. 이를 위해 시민들과 $\mathrm{CSO}$ 의 자유로운 표현과 집회의 자유를 보장해 다양한 계층의 목소리가 여론으로 수렴되는 과정을 지원해줄 필요가 있다. 인터넷과 정보통신기술(Information Communication Technology, 이하 ICT) 보급도 시민들의 자원봉사 논의와 참여를 진흥하는 중요한 정책도구가 된다. 브라질에서는 정부와 시민사회가 공조해 공공 보건의 균등한 배분을 위한 새로운 보건정책 시행에서 자원봉사 를 적극 활용하였다. 언론을 활용하고 인터넷과 눈 등의 새로운 미디어의 활용으로 청년층의 참여를 활성화하는 방안들도 개발도상국 여러 곳에서 진행 중이다. 스리랑카에서 정부군과 반군 사이의 내전이 있었던 2009년 이후 2011년 정부는 내전의 교훈과 화해위원회의 보고서에 정부와 시민사회의 확고한 파트너십을 중시했고, 이 내용을 자원봉사자들이 지역사회 주민들과 단체들에 전달해 평화과정의 참여와 인식 제고에 기여하였다(UNV, 2015c:xvii).

글로벌 차원에서도 다양한 자원봉사 네트워크들이 개발도상국의 시민 요구, 참여, 책무성과 투명성 증진에 기여할 수 있다. ICT 기술의 활용으로 개발도상국의 정부와 시민사회(CSO)의 자원봉사 제도와 정책, 정보와 교육훈련 등 다양한 역량 개선의 환경을 조성하고 기회를 부여할 수 있다.

\section{SDGs 달성에 기여하는 자원봉사의 임팩트}

\section{1. 자원봉사의 인적/사회적 자본 임팩트}

자원봉사가 SDGs 달성에 중요한 수단이 되는 이유는 시민 개인들의 지식, 역량 등 인적 자본(human capital)뿐 아니라 시민들과 단체들의 협력과 신뢰와 유대 등 사회적 자본(social capital)을 생산하고 증대시키기 때문이다. 자원봉사는 “시민들과 지역사회가 자신들의 성장에 참여”하게 하고, 시민들은 자원봉사를 통해 원기를 회복하고 지식의 기반을 개선해 공동체를 위한 책임감을 갖게 된다(UNV, 2015a). 또 자원봉사 활동을 통해 사회적 통합과 신뢰가 강화 되면서 시민들에 의한, 시민들을 위한 지속가능한 결과를 생산한다(UNV, 2015a). 자원봉사는 취약층에 대한 서비스 지원뿐 아니라 시민의식과 시민참여를 고양하며, 사회적 배제를 차단하고 사회적 포용을 지향해 연대와 사회통합을 지향한다. 또한 자원봉사자들이 활동을 통해 다른 자원봉사자들의 참여에 영향을 미치며, SDGs가 지역사회에 정착되기 위한 중요한 변혁을 이루 도록 기여한다. 
이 같은 자원봉사의 개발 임팩트 가치는 오래 전부터 UN 등의 국제기관에서 확인한 바가 있다. UN은 2001년 ‘국제 자원봉사자의 해’를 추진해 각국의 자원봉사활동을 진홍, 활성화시켰 다. UN 총회는 자원봉사가 "빈곤 감소, 지속가능한 개발, 보건, 재난 예방과 관리, 사회적 배제 와 차별을 극복하는 전략에 중요한 요소”라 천명하면서, 각국이 자원봉사에 대한 “지식 기반”을 확충해서 “자원봉사의 경제적 가치를 수립” 할 것을 권고하였다(UNGA, 2001). UNV는 1998 년 특별보고서『자원봉사와 사회개발』에서 자원봉사를 통한 사회개발의 가치를 중시하고 (UNV, 2000), 2011년 보고서에서도 자원봉사를 사회개발과 국제협력의 전략으로 간주한다 (UNV, 2011).

자원봉사의 '인적 자본' 임팩트는 지역사회 차원에서 확인될 수 있다. 지역주민들이 자원봉사 를 통해 다양한 인적 자본을 개선하는 것이다. 새로운 인간관계의 기술, 사회문제 해결의 방안, 시민적 권리에 관한 이해 등 개발의 밑거름이 되는 것들이다(UNV, 2015c). 나아가 자신과 이웃을 넘어 다른 세계에 대한 관심과 이해, 정부의 정책에 대한 이해, 동시에 문제해결에 필요 한 자발적인 단체 조직으로 지역과 국가 차원의 문제 해결에 선도적 역할을 할 수 있다. 특히 자원봉사는 여성과 취약층의 자치역량(empowering)의 주요 수단이자 시민문화로 발전될 수 있다. 지역사회 차원의 자원봉사 참여의 개발은 지역사회가 주도할 수도 있지만, 국가 차원의 지원과 글로벌 네트워크를 통한 다양한 시민사회조직들과 자원봉사 전문기관들이 공조적 파트 너 역할을 할 수 있다.

자원봉사의 가치는 인적 자본의 강화로 사회변화를 위한 환경을 창출하는 지속가능성에 있다 고 볼 수 있다. 자원봉사의 내재적 가치는 자원봉사자들이 실제 어떤 활동을 하는지, 어떤 기술 과 지식을 활용하는지에 머물지 않고 그들이 변화를 지원하기 위해 조직들과 지역사회와 어떻게 공조하는지, 중장기적인 임팩트에서 찾게 된다. 자원봉사의 연대, 상호 호혜성, 상호 신뢰, 존중 및 공조적 학습이 중요하며, 자원봉사자들은 융통성, 적응성, 접근성, '할 수 있다'는 접근, 그리 고 금전적 보상 보다 더 가치 있는 변화에 대한 지지의 동기 등 개인적 자질을 갖추게 된다 (VSO, 2016:6). 지역사회나 조직에서 활동하는 자원봉사자들은 비슷한 수준의 소득과 생활 환경에서 동료와 지역사회 구성원 사이의 동등하며 신뢰하는 유대적 관계를 갖게 된다. 자원봉 사자들은 집단행동의 촉매자 역할도 하며 지역사회 내에서 그리고 지역사회를 넘어 정보, 네트 워크, 자원에 대한 접근의 중개자 역할도 한다. 자원봉사활동은 소프트 성과와 하드 성과를 통해 인적 자본을 강화하는 기능을 한다. 하드 성과란 포용적 강사법과 같은 전문기술이나 기술적 지식의 개선으로 나타나며, 소프트 성과는 개인의 사고방식과 행태에서의 근본적인 변화로 도덕과 윤리, 자기 확신, 문제 해결과 분석기술 개선, 타인과의 협조적 활동 등으로 
나타난다. 이런 하드 및 소프트 변화는 사회변화를 위한 결정적인 선결조건이 되며 사람들이 개발의 수동적 수혜자에서 능동적 참여자로의 변혁을 지원해준다(VSO, 2016:6). '변화의 이론 (theory of change)' 시각에서는 이런 변혁이 이뤄질 때 빈곤퇴치 등의 획기적인 임팩트를 기대해볼 수 있다.

또 자원봉사가 개발에서 중요한 정당한 근거는 사회자본과 사회통합에서 찾아볼 수 있다 (UNV, 2011). 첫째, 자원봉사는 도움을 필요로 하는 사람들을 대상으로 하는 활동이지만 공동 체 구성원들 사이의 유대와 연대, 그리고 신뢰의 바탕에서 행해지는 상호 공조적 활동이라고 볼 수 있다. "시간을 제공하는 일은 신뢰에 기초하는 활동으로 사회의 조직을 강화시키고 우리가 거주하는 공동체를 규정하는 일이다." 둘째, 신뢰를 바탕으로 하는 자원봉사는 “사회적 상호작 용의 네트워크와 상호성의 규범, 즉 사회자본의 표현이다." 자원봉사활동은 새로운 관계를 발전 시키며 새로운 네트워크와 규범을 생성시키는 활동이다. 셋째, 자원봉사는 시장이 효과적이지 않은 영역에서 소외층의 좌절, 무관심으로부터 보호하는 인간적 활동이다. “자원봉사는 개인의 공동체 참여를 표현하는 일이다.” 넷째, 자원봉사는 소외층과 불이익계층의 요구에 호응하며 이들의 민족적, 인종적, 종교적 다양성에 관대한 관용의 정신을 키워준다. 다섯째, 자원봉사는 소득, 성, 연령 등 계층에 기초하는 분열과 갈등의 사회에 조정과 통합을 모색하는 기능을 하며 기여한다. 여섯째, 자원봉사는 무수한 유대와 연대에 기초하는 사회자본을 구축하며 공공기관과 의 파트너십을 통해 빈곤퇴치, 사회통합, 지속가능한 개발에 기여한다.

\section{SDGs 달성에 기여하는 자원봉사의 임팩트}

보다 구체적으로 자원봉사가 SDGs 달성에 기여하는 방법들은 다음과 같이 다양하다(UNV, 2015b).

- SDGs 인식 증진(소외지역과 소외층 포용 캠페인 등) 전문 기술의 제공

- 기획, 실행, 모니터링 과정의 시민참여로 대화와 행동의 장 확장

- 시민주도의 질적, 양적 자료수집으로 SDGs 진전도 모니터링

- 지식 공유 및 이전 증진과 지역 전문기술의 타 지역 보급 확대

- 기초 서비스 부족 지역과 대상층에게 서비스 보충

- 지역의 SDGs 증진을 위한 모범적 행태와 사례 보급

이상과 같은 기여를 통해 자원봉사는 SDGs의 임팩트가 되는 개발과 평화에 대해 다음과 같은 임팩트를 생산할 것으로 기대된다(UNV, 2015b). 
- 참여의 포용적 공간 확장

- 역량개발의 개선과 기술 개발

- 각계각층의 유대적 사회자본과 신뢰 구축

- 지역 현안들에 대한 기회와 오너십 개발

- 시민참여 증대로 지역 거버넌스와 책무성 강화

- 대응력과 준비 강화, 지식 향상과 공동체 책임감 증진

- 시민참여로서 자원봉사에 호혜적인 환경 구축

$\mathrm{UN}$ 에 따르면, 자원봉사정신과 자원봉사자는 SDG 목표 1 부터 17 까지 전체 분야에 걸쳐 변혁적 실천으로 기여한다(UNV, 2015b). 2014년의 2030 어젠다에서도 자원봉사단체가 SDGs 모든 목표 실행의 주요 행위자로 간주하였다. 보다 구체적으로 SDGs 개별 목표 달성에 기여하는 자원봉사의 가치는 먼저 기술지원자 역할에서 찾아볼 수 있다. 17 개의 SDGs 가운데 보건(목표 3), 교육(목표 4), 식수와 위생(목표 6), 재생에너지(목표 7), 지속가능한 생태계(목표 $13,14,15)$ 등은 자원봉사자의 기술지원이 많이 필요한 분야이다. 또 자원봉사자들은 청년이나 고용시장 접근의 기회가 제한적인 취약층의 고용가능성을 개선시키는데 중요한 영향을 미친다 (목표 8과 모든 SDGs). 또 자원봉사는 개인의 행태 모델링과 행태적 개선에서 입증된 기록을 보여주므로, 자원봉사의 활용으로 젠더 평등(목표 5), 식수와 위생(목표 6), 지속가능한 소비(목 표 12), 기후행동(목표 13)과 관련된다. 또 자원봉사는 인간관계 개선, 신뢰 구축으로 사회적 자본과 사회통합에 기여하므로 SDG 16 의 평화와 사회정의와도 관련된다.

나아가 다음과 같은 자원봉사자의 기술과 역량으로 SDGs에 대한 기여가 이뤄질 것으로 기대된다(UNV, 2015b). 첫째는 2030 어젠다에 대한 인식 제고이다. 자원봉사활동은 농촌 과 오지에서 취약층을 대상으로 지역 캠페인과 창의적 접근법으로 SDGs의 국내화에 기여한 다(모든 목표). 둘째는 기술 지원이다. 'MDGs의 미완의 비즈니스(목표 1 부터 5까지)'의 기본적인 서비스 부족에 대한 보충적 역할을 하며, 다른 SDGs(목표 6, 7, 13-15)에서도 기술지원의 역할이 중요하다. 셋째는 행태의 모델링으로 2030 어젠다의 진정한 변혁이 일어 나도록 지원하는 밑거름이 되며, 지식과 긍정적 의지의 개선으로 SDGs의 지방화에 기여한 다(목표 $5,6,12,13,16)$. 넷째는 기술 개발이다. 지식과 경험의 전수로 SDGs 많은 목표들에 적용되며 지역의 기술 보급을 촉진시키는 역할도 하며 SDGs 달성에 기여한다(목표 8과 모든 목표들). 마지막은 자료의 수집과 SDGs 진도의 사정이다. 참여적 모니터링, 지역 현장 방문, ‘My World 2030 서베이’의 보급 확장 등으로 지역의 전문성을 증대한다(목표 17 과 모든 목표). 


\section{SDGs 실행을 위한 자원봉사 파트너십 추진 방안}

\section{1. 위, 이래, 밖으로부터의 공조}

제I장

리더십 역할이라고 볼 수 있다. 최근 일부 국가들에서 자원봉사 법과 제도가 도입된 것은 재난 구호의 긴급성 등 다른 요인들도 중요했지만 국가 리더십의 역할이 결정적으로 중요했다(UNV, 2011a, 2011b; 주성수, 2013).

둘째, 아래로부터의 공조는 자원봉사에 대한 국민적 관심과 참여라고 볼 수 있다. 빈곤으로 어려움에 처한 국가들에서도 이웃 간에 서로 돕고 물질을 기부하며 조직적으로 봉사활동을 하는 나눔문화가 점차 진전되고 있다. 갤럽 인터내셔널(Gallup International)의 글로벌 서베 이 결과를 보면, 자원봉사 참여율(15세 이상 인구)은 유럽 $19 \%$, 남미와 북미 $25 \%$ 수준인데, 아시아 23\%, 아프리카 20\%로 성장해 있다(CAF, 2016:29). 또 기부와 타인 돕기에서도 유럽 $36 \%$ 와 $44 \%$, 남미와 북미 $29 \%$ 와 $54 \%$ 인데 비해 아시아 $37 \%$ 와 $51 \%$, 아프리카 $18 \%$ 와 $58 \%$ 로, 물질적 기부에서만이 아프리카가 다소 뒤질 정도로 나눔문화는 빈약하지 않다. 특히 국가개발에 국민들의 참여와 정책결정에 대한 영향력 행사도 SDGs 시행에서 중요하다. "국민들이 정책결 정 과정에 영향력을 행사하고 또 자신들의 삶에 영향을 미치는 외부 행위자들과 제도들에 압력 을 행사할 역량을 강화”하는 거버넌스의 전환이 중요하다(UNDP, 2017:29).

셋째, 밖으로부터의 공조는 타국과 글로벌 차원의 자원봉사 진흥을 지원하는 인적, 물적 지원 이라 볼 수 있다. UNV와 공조하는 UN 기관들, $\mathrm{KOICA}$ 를 비롯한 각국의 해외봉사단, 세계자 원봉사협의회(International Association for Volunteer Effort, IVAE), 세계시민사회연합 (World Alliance for Citizen Participation, CIVICUS) 등 글로벌 시민사회 연대조직, 한국 과 각국의 기업들과 국제상공회의소 등의 기업연맹과 중간지원조직 등, 무수하고 다양한 공적, 민간, 시민사회 조직들이 개발도상국과 글로벌 차원의 자원봉사 진흥을 지원해 SDGs 달성에 기여하는 역할을 한다.

위-아래-밖으로부터의 공조는 개발도상국의 정부-기업-시민사회 차원과 국제사회의 정부 와 국제기관, 기업/기업연맹, NGO와 글로벌 네트워크 등으로 구분해 SDGs 달성을 위한 자원 봉사의 변혁적 파트너십 추진 방안을 제시해볼 수 있다(표 1). 자원봉사를 개발도상국의 SDGs 
추진 전략으로 활용하는 방안으로, 국제사회 파트너들인 정부/국제기관, 기업/기업연맹, NGO/ 글로벌 네트워크 각각의 개발도상국의 국가(정부), 시장(기업), 시민사회(NGO/자원봉사조직) 을 공조적 파트너십으로 지원하는 방안들이다.

\section{2. 정부의 자원봉사 제도화 지원방안}

$\mathrm{SDGs}$ 의 국가 차원의 추진은 중앙정부의 주도로 국내의 기업과 시민사회가 공조적으로 이뤄 지기 때문에 우선 정부의 기능과 역할에 초점을 맞춰볼 수 있다. 여기에서 핵심은 법과 제도의 마련이며, 이를 지원하는 적절한 기금의 조성과 자원봉사 활동을 개설 또는 진흥하기 위한 인프라(제도와 조직 등)와 재정과 행정과 운영과 프로그램 등이 복합된 생태계의 조성이 중요하 다(주성수, 2016b). 이 세 가지 부문 각각이 국제사회의 정부와 국제기관 차원, 기업과 기업연맹 차원, 시민사회 차원으로 구분될 수 있는데, 추진 방안의 적절한 조합은 개발도상국의 국내 사정과 욕구에 따라 다양한 조합이 가능하다. 표에서는 일반적으로 지원방식을 파트너 기능으로 구분해 보여준다.

국가개발목표에 기여하는 자원봉사의 활용 전략 수립이 중요하다. 법과 제도의 기반을 구축 한 다음 자원봉사자들의 활동을 지원하는 기회를 제공하는 것이 중요하다(UNV, 2015c:39). 자원봉사활동이 국가개발목표 시행에 기여하며 사회통합, 사회문제 해결에 직접적으로 기여한 다. 자원봉사 진흥에 선도적인 역할을 하는 정부들이 자원봉사를 개발 어젠다의 실행에 핵심 정책수단으로 간주하고 있다는 것이다. 이에 자원봉사자들은 정부의 역할에 호응하는 의미에 서 자원봉사 법과 제도의 개선과 홍보에 지지적인 활동을 하며 정부의 정통성 지지기반이 된다. 자원봉사자들은 직접 정부의 사회경제 프로그램에 참여해 기술과 교육훈련 참여에도 지지적이다.

개발도상국 중에는 온두라스, 모잠비크, 페루가 자원봉사 법과 제도를 갖춘 대표적인 사례로 소개된다(UNV, 2015c:39-40). 정부가 자원봉사 전문기관 등의 핵심 이해관계자들의 법 제정 과정에 참여를 독려했다. 온두라스는 2011년 의회 입법으로 공공, 민간, 시민사회 조직에서 국가개발의 활동을 지원하는 정책을 추진해왔다. 페루의 경우, 법적 제도화 이외에도 자원봉사 행정국의 개설 등 행정지원 체제 구축이 특징적이다. 1988년 이래로 25 억 이상의 아동이 홍역 예방주사 혜택을 보게 된 것은 200개국 이상이 공조했고, 국제적 재정 투자와 2천만 명에 달하 는 자원봉사자들의 지지도 뒷받침되었다. 
〈표 1〉 SDGs 실행을 위한 자원봉사의 변혁적 파트너십 추진 방안

\begin{tabular}{|c|c|c|c|}
\hline 개발도상국 국제사회 & 정부와 국제기관 & 기업과 기업연맹 & $\begin{array}{c}\text { 시민사회 } \\
\text { (NGO/자원봉사조직) }\end{array}$ \\
\hline $\begin{array}{c}\text { 정부 } \\
\text { (중앙, 지방정부) }\end{array}$ & 바법, 제도, 정책, & $\begin{array}{l}\text { 4) 자원봉사 제도화진흥 } \\
\text { 기금 }\end{array}$ & $\begin{array}{l}\text { 7) 자원봉사 인프라와 생태 } \\
\text { 계 전략수립 }\end{array}$ \\
\hline $\begin{array}{c}\text { 기업 } \\
\text { (직장, 해외기업) }\end{array}$ & $\begin{array}{l}\text { 2) 자원봉사-일지리 사업 } \\
\text { 지원 }\end{array}$ & $\begin{array}{l}\text { 5) 직원자원봉사 글로벌 네 } \\
\text { 트워크 }\end{array}$ & $\begin{array}{l}\text { 8) 직원자원봉사 프로그램 } \\
\text { 과 리더 개발 }\end{array}$ \\
\hline $\begin{array}{c}\text { 시민사회 } \\
\text { (NGO/자원봉사조직) }\end{array}$ & $\begin{array}{l}\text { 3) 자원봉사 기반의 개발협 } \\
\text { 력사업 }\end{array}$ & $\begin{array}{l}\text { 6) 지원봉사 혁신과 역량 강 } \\
\text { 화 기금 }\end{array}$ & $\begin{array}{l}\text { 9) 자원봉사조직(센터) 설 } \\
\text { 립, 관리자교육 }\end{array}$ \\
\hline
\end{tabular}

출처: 저자 작성

\section{3. 기업의 '포용적 비즈니스' 지원방안}

기업, 공공기관 등 직장을 통한 자원봉사활동은 많은 국가에서 일반화되어 있다. 개발도상국 의 경우도 국내 기업뿐 아니라 해외 기업들이 사회적 책임(Corporate Social Responsibility, $\mathrm{CRS}$ ) 차원으로 추진하는 다양한 지역사회 봉사활동이 점차 늘고 있다. 또 $\mathrm{KOICA}$, 미국 평화 봉사단(Peace Corps), 일본 국제협력기구(Japan International Cooperation Agency, JICA), 해외자원봉사(Voluntary Service Overseas, 이하 VSO) 등의 개발협력 프로그램에 도 중소기업의 육성 지원과 청년 구직 지원 등으로 자원봉사자 활용을 확대해볼 수 있다(주성수 외, 2015). UNV(2015b)는 자원봉사 프로그램은 청년이나 고용시장 접근 기회가 제한적인 취약층의 고용가능성을 개선시키는데 중요한 임팩트를 창출해, SDG 8을 비롯한 모든 SDGs 달성에 기여한다고 강조한다. 가나와 케냐에서는 청소년들이 농촌 봉사활동으로 주민의 교육과 보건 개선에 기여하는 기회를 제공하고, 청년 취업의 디딤돌로 삼았다(UNV, 2015c:39). 의회 의 청소년 위원회는 자원봉사 예산을 배정했고, 법 제정 과정에는 자원봉사 기관들의 참여에 의한 거버넌스가 작동되었다.

국제사회의 정부와 국제기관들은 개발도상국 기업과 일자리 지원사업의 한 방안으로 자원봉 사자 활용, 인턴십 지원 등을 추진할 수 있다(<표 $1>$ 참조). 또 기업과 기업연맹도 직장의 $\mathrm{CSR}$ 형태의 직원자원봉사 활성화에 재정지원이나 글로벌 네트워크 공유 등의 연대활동으로 직원자원봉사의 필요성에 대한 인지, 이해, 학습, 정보교환, 워크솝과 심포지엄 지원 등 다양한 교류가 이뤄질 수 있다. 또 개발 $\mathrm{NGO}$ 들과 자원봉사조직들도 직원자원봉사 프로그램의 개발과 운영에 대한 자문, 개발지원 사업의 파트너로서 기업과 직장인의 자원봉사 참여 등 다양한 공조적 파트너십이 추진될 수 있다. 


\section{4. 시민사회의 '역량 강화' 지원방안}

개발도상국의 강력한 시민사회의 성장은 개발협력의 효과성 증진의 주요 전략중 하나이다. 시민사회는 시민들의 자발적인 참여와 활동으로 성장하기 때문에 다양한 시민사회단체(NGO) 들을 통한, $\mathrm{NGO}$ 를 위한 시민들의 자원봉사는 국가별 SDGs 추진전략의 핵심을 차지할 정도로 중시된다. 모잠비크는 2010년 자원봉사 법을 제정했는데, 정부가 2009년에 빈곤퇴치에 기여하 는 $\mathrm{CSO}$ 의 역량 강화를 위해 설치한 국가자원봉사위원회가 기초한 것이다(UNV, 2015c:39). 법 제정 과정은 참여적 과정으로 법의 기본안 마련, 시행과 모니터링 등을 지원하는 과정이 되었다. 자원봉사법은 한편으로는 민주주의, 인권, 국가통합, 사회복지, 재난대응, 환경보호 등 국가개발목표를 진흥하는 것이며, 다른 한편으로는 자원봉사의 지원과 인정, 효과적인 자원봉사 관리 방안에 관한 것이다.

자원봉사 역량 강화는 조직들이 더 많은, 양질의 직접 서비스를 지속적으로 제공하도록 지원 하는 간접 서비스(Indirect Service) 제공을 말한다(CNCS, 2011: 6). 간접 서비스는 "조직이 나 프로그램의 핵심 미션, 의무사항 및 프로그래밍을 수행하도록 지원하는 기술, 능력, 지식, 노력의 제공”을 의미한다. 자원봉사 역량 강화로 기대되는 의도적 결과들로는 1) 프로그램 공급 모델의 지원이나 개선, 2) 조직의 서비스 증대, 확장 또는 개선의 목표에 대한 호응, 3) 간접서비스 제공 참여자들의 서비스 활동이 종료되어도 조직의 많은, 지속적인 양질의 직접 서비스 제공 가능성 등이다. 역량 강화는 주요국 해외봉사기관의 핵심 추진 전략이다(주성수 외, 2015). 평화봉사단(Peace Corps, 2013)은 2014-17년 전략기획에 “자원봉사자의 역량구축 활동”을 중시해, “지역의 기관들과 개인들이 개발문제 해결에 필요한 기술들을 강화시켜, 지역 생활의 개선에 기여한다."고 밝힌다. 영국의 VSO 또한 직접 서비스의 제공을 통해 파견지역의 빈곤퇴치를 해결하는 방식보다 파견지역 이해관계자들의 역량 강화를 통한 개발협력 목적 달성 을 추구하는 간접 방식을 추진전략으로 삼고 있다(VSO, 2014, 2016).

국제사회가 개발도상국의 시민사회의 역량 강화 차원으로 지원할 수 있는 자원봉사 프로젝 트는 먼저 정부와 국제기관 차원에서는 개발협력 사업에 자원봉사를 적극 활용하는 방안이다. 개발협력 분야는 일반적으로 교육, 보건, 농수산업, 경제, 행정, 정보기술(Information Technology, IT), 환경 등으로 추진되는데 거의 모든 분야에 자원봉사가 통합되어 개발의 효과성을 증진시킬 수 있다. 앞서 SDGs 모든 분야에 자원봉사가 통합될 것을 제시한 UN의 $\mathrm{SDGs}$ 추진전략을 참고해볼 수 있다. $\mathrm{KOICA}$ 의 경우 젠더 이슈와 환경 이슈를 범분야로 분류한 것처럼 자원봉사도 여기에 포함시켜 범분야로 정책 우선순위를 두는 전략이 중요하다. 다음으로 국제사회의 기업과 기업연맹의 경우 시민사회 역량 강화에 필요한 인프라 지원, 특히 
시민사회의 자원봉사 혁신과 역량 강화에 필요한 기금 지원이 긴요하다. 국제사회의 $\mathrm{NGO들과}$ $\mathrm{INGO}$ 그리고 자원봉사 전문조직들도 개도국의 자원봉사 생태계 조성에 필요한 전문기술, 자원봉사센터 등의 제도화, 지도자 역량 강화 프로그램 개발과 운영에 직접적으로 기여할 수 있다.

\section{5. 국내-국제 자원봉사의 통합 추진전략}

마지막으로, 개발도상국 자원봉사 진흥을 지원하는 국제사회의 지원 전략과 추진 방안으로

개도국 국내의 자원봉사와 국제사회의 자원봉사가 연계, 통합이 이뤄질 필요가 있다. 국내 봉사 자와 국제봉사자가 SDGs 분야별로 프로젝트나 프로그램 단위에서 공조함으로써 SDGs 달성 에 시너지 효과를 발휘할 것으로 기대된다. 특히 국제봉사자들의 지식, 경험, 전문기술이 국내봉 사자들에게 전수, 보급되어, 개발의 오너십과 역량 강화 전략으로 추진될 수 있을 때 개발협력의 지속가능한 임팩트를 기대할 수 있다. 국제봉사자와 국내봉사자의 공조와 협력 모델은 VSO의 오랜 전통이다(VSO, 2014; Devereux and Allum, 2016). 또 2011년 개시한 영국의 DFID 재정지원으로 VSO가 운영하는 ICS(International Citizen Service)는 영국 봉사자(UKV)와 수원국 봉사자(In-country volunteer, 이하 ICV)의 협력을 7 개 기본원칙 중 하나로 제시한다. '다른 국가들의 청년들 사이의 공유된 활동과 학습은 프로그램의 핵심 측면'이라 밝힌다. ICS 사업의 중간평가 결과 수원국 파트너기관의 $98.4 \%$ 가 ICS 프로그램을 긍정적으로 평가하고, $\mathrm{ICV}$ 의 $100 \%, \mathrm{UKV}$ 의 91\%가 프로그램이 유익했다고 답했다(DFID, 2011).

또 다른 혁신적인 글로벌 자원봉사 프로젝트로 유럽연합(European Union, 이하 EU)의 AID 자원봉사(AID Volunteers) 이니셔티브를 참고해볼 만하다. 인도적 구호를 목적으로 자원봉사자와 단체들이 세계의 현장에서 지역사회가 재난의 복구, 대응, 예방 역량을 갖추도록 지원하는 인도적 구호 자원봉사 프로젝트로, 모집된 개인과 단체를 대상으로 교육훈련과 재정을 지원한다(EU, 2016). 5년 이상의 전문 경력자 시니어 프로그램과 18 세 이상 청년 참여의 주니 어 프로그램이 있다. 2015년부터 6개의 역량 강화 프로젝트가 시행되어 66개 파트너 조직들이 참여했고, 4 개의 기술지원 프로젝트가 시행되어 22 개 파트너 조직들이 참여했다. 12 개국에 26 개 시민사회단체들과 44 명의 자원봉사자들이 기술지원 자원봉사 활동에 참여했다. 프로젝트 활동으로는 프로젝트 관리, 커뮤니케이션, 도시 복구, 젠더, 교육, 로지스틱스 등이다. AID 자원봉사를 계기로 $\mathrm{EU}$ 는 인도적 구호기관들의 자원봉사자 관리에 관한 유럽 표준방안을 갖춰, 인도적 구호 현장 배치에 앞서 자원봉사 교육과 소양 등 준비를 지원한다. 2016-20년 기간에는 약 4천 명의 자원봉사자가 인도적 구호 기관들의 모집으로 교육훈련을 거쳐 글로벌 현장에 
배치될 예정이다. 프로젝트는 매년 정기적인 공모에 의해 진행되는데, 자원봉사 교육훈련은 온라인과 오프라인 교육장을 통해 진행되며, 교과로는 유럽의 위기대응 시스템, 인도적 구호 개론, 안전과 안보와 건강 관리, 프로젝트 관리, 다문화 이해, 주창과 커뮤니케이션, 응급조치, 자원봉사 관리와 조직 개발 등이다.

\section{V. 맺는말}

자원봉사 생태계는 개발도상국의 SDGs 국가개발계획의 하나로 도입, 추진될 수 있다. 자원 봉사 생태계 조성이 SDGs 달성에 필수적인 자원봉사 활성화에 핵심이 되기 때문이다. 개발도 상국들이 공통적으로 당면하는 자원봉사 생태계 조성의 어려움을 극복하기 위한 국제사회의 지원 방안들을 정리해보면 다음과 같다.

첫째는 자원봉사 법과 제도의 도입과 시행에 필요한 전문가 양성과 재정적 지원이다. 국가에 따라 리더십이나 재난 등이 자원봉사의 법과 제도화를 촉진시킨 주요 요인들이 되었지만, 이제 는 SDGs 달성의 핵심 전략으로 자원봉사 활용을 법과 제도화로 추진할만한 강력한 근거가 마련된 것이다. 국제사회는 글로벌 차원의 자원봉사 진흥을 지원하면서 개별 국가들의 자원봉사 제도화에 필요한 전문 인력과 리더십 개발 등에 소요되는 자원봉사 임팩트 기금을 제공하는 중장기 방안이 필요하다.

둘째는 자원봉사센터의 개설 지원이 단기적인 추진 방안이 될 만하다. 자원봉사센터는 일반 적으로 중간지원조직의 역할을 하면서 지방 단위부터 광역과 중앙 단위에 개설되어 자원봉사를 필요로 하는 수요처의 수요 개발에 SDGs 시행을 접목해볼 수 있다. 자원봉사센터는 앞서 소개한 중간지원조직의 역할을 수행하는데 3-4명의 역량을 갖춘 스태프들과 많지 않은 예산으 로 운영될 수 있기 때문에 실행 가능한 추진 방안이 될 수 있다. $\mathrm{KOICA}$ 의 경우 해외사무소와 연계해 개발협력 사업에 현지 국내 자원봉사자와 한국인 자원봉사자와의 통합적 접근법을 개발 해 추진하는데 현지의 자원봉사센터를 주요 인프라로 구축해볼 수 있다. 자원봉사센터는 한국의 자원봉사 전문기관 대표들이 자원봉사센터의 운영과 관리, 프로그램 개발과 시행, 전문 인력의 역량 강화 교육훈련 등에서 많은 지원 활동을 할 수 있다.

셋째는 자원봉사를 범분야 개발전략으로 중시해볼 수 있다. KOICA의 경우, 교육, 보건, 공공행정, 농립수산, 기술/환경/에너지, 범분야 등 여섯 사업 분야로 개발협력을 기획해 추진 한다. 여기에 자원봉사를 범분야(환경/여성/ICT/인권)에 포함시켜, 모든 개발협력 사업에서 
자원봉사를 적극 활용해 개발 임팩트를 지향하는 추진전략을 제시해볼 수 있다. 앞서 살펴보 았듯이 자원봉사가 SDGs 달성에 기여하는 전략 도구이자 국민과 참여 중심의 개발이라는 목표와 비전과도 일치하기 때문이다. 이런 의미에서 UNV 등 UN 기관들과 Peace Corps, $\mathrm{VSO}$ 등의 해외봉사기관들도 자원봉사의 활용 방안을 확장해 개발 임팩트 증진을 추진하고 있다.

\section{제 I 장}




\section{〈참고문헌〉}

주성수. 2013. 『자원봉사 문화와 제도』. 서울: 한양대 출판부.

2016a. 『나눔문화 : 기부, 자원봉사, 이웃돕기, 시민참여』. 서울: 한양대 출판부. 2016b. “한국 자원봉사는 지속가능한가? 자원봉사 생태계 진단." 2016 전국 자원봉사 컨퍼런스(2016.08.29.-08.30. 제주도 오리엔탈 호텔) 발제문. 주성수·김성현. 2014. “글로벌 CSR 현황과 추진 방안.” 성남: 한국국제협력단. 주성수 외. 2012. “자원봉사 진흥을 위한 제2차 국가기본계획 수립.” 서울: 행정자치부. 주성수 외. 2015. “해외봉사 효과성 증진을 위한 추진 전략." 성남: 한국국제협력단.

CAF(Charity Aid Foundation). 2016. "World Giving Index 2016.” London: CAF. CNCS(Corporation for National \& Community Service), 2011. "Demonstrating Impact through Capacity Building." Washington, D.C.: CNCS.

DFID. 2011. "Evaluation of DFID's International Citizen Service (ICS) pilot stage - mid term review." London: DFID.

Devereux, P. and Allum, C. 2016. "The interface between International and National volunteering and the implications for IVCOs." IVCO 2016 Conference, held in Bonn from 9-12 October 2016.

EU. 2016. "EU Aid Volunteers," Brussels: EU.

ILO International Labor Organization). 2011. "Manual on the Measurement of Volunteer Work.” Geneva: ILO.

Peace Corps 2013. “Strategic Plan, FYs 2014-2018.” Washington, D.C.: Peace Corps.

UN. 2014. "The road to dignity by 2030: ending poverty, transforming all lives and protecting the planet." New York : UN.

_. 2015. "Transforming our world: the 2030 Agenda for Sustainable Development." New York: UN.

UNDP. 1997. "Governance for Sustainable Development: Glossary of Key Terms." New York: UNDP. 2017. "Youth as partners for the implementation of the SDGs." New York: UNDP. 
UNGA. 2001. "Support for Volunteering : Report of the Secretary General." New York: UN.

. 2013. "A Life of Dignity for All: accelerating progress towards the Millennium Development Goals and advancing the United Nations development agenda beyond 2015.” New York: UN.

2015. "Resolution 70/129: Integrating volunteering into peace and development: the plan of action for the next decade and beyond." New York: UN.

UNV(United Nations Volunteers). 2000. "Roundtable on Volunteering and

Social Development." Bonn: UNV. 2009. Laws and Policies Affecting Volunteerism since 2001. Bonn :

\section{UNV.}

2011a. The State of the World's Volunteerism Report. Bonn: UNV. 2011b. "Broadening the Civic Space through Voluntary Action." Bonn: UNV.

. 2014. "UNV Strategic Framework: 2014-2017." Bonn : UNV. . 2015a. "Integrating Volunteering in Peace and Development: The Plan of Action for the next decade and beyond: 2016 -2030.” Bonn: UNV. 2015b."UNV Toolkit: How volunteerism can contribute to achieving the SDGs." Bonn: UNV. 2015c. State of the World's Volunteerism Report 2015 : Transforming governance. Bonn: UNV.

VSO. 2014. “Annual Report and Financial Statements.” London: VSO. 2016. "VSO's Global Theory of Change." London: VSO. 